\title{
Pengembangan Perikanan Tangkap dan Hasil Olahannya di Pesisir Kabupaten Bone Bolango Gorontalo
}

\author{
Frahmawati Bumulo ${ }^{1)}$, Meyko Panigoro ${ }^{2)}$ \\ ${ }^{1)}$ Dosen Jurusan Ilmu Ekonomi, Universitas Negeri Gorontalo \\ ${ }^{2)}$ Dosen Jurusan Pendidikan Ekonomi, Universitas Negeri Gorontalo \\ frahmawatibumulo@ung.ac.id, meyko.panigoro@ung.ac.id
}

\begin{abstract}
The purpose of this research is, how to develop capture fisheries and their processed products on the coast of Bone Bolango, Gorontalo Province. The analytical methode used in this research is SWOT analysis. The SWOT analysis methode is used to analysis capture fisheries development strategies in Bone Bolango Gorontalo Province.

The results showed that from the results of the SWOT analysis, a capture fisheries development strategy and its processed products in increasing Regional Original Income were described in several aspects, a) Improving facilities and infrastructure for coastal area development, b) Disseminating information about coastal and marine resources through local media an national, c) Developing appropriate models and technologies and environmentally friendly use of marine resources, d) Supporting groups of fishermen the production of processed capture fishery products, f) Incresing the capacity of fishing communities regarding the utilization and management of capture fisheries resources,
\end{abstract}

\section{Keywords : Capture Fisheries Development and Processed Product}

\section{PENDAHULUAN}

Wilayah Republik Indonesia sebagaian besar berupa laut oleh karena itu Pembangunan Kelautan memiliki peranan yang sangat penting dalam meningkatkan Pendapatan Nasional, Wilayah Indonesia yang disebut juga benua maritim dan sebagai archipelagig state (Negara Kepulauan) dengan luas laut 5.8 juta km2 indonesia memiliki keunggulan komparatif dalam potensi sumberdaya perikanan dan kelautan. Laut Indonesia terbagi dalam wilayah Zona Ekonomi Ekslusif (ZEE) seluas 2.7 juta $\mathrm{km} 2$. Dengan demikian sebebarnya indonesia dapat memanfaatkan sumber daya alam di perairan luasnya sebesar 5.8 juta km2.

Komisi Nasional Pengkajian Sumber Daya Perikanan Laut (1998) 
melaporkan bahwa potensi lestari sumber daya perikanan laut Indonesia adalah sebesar 6.167.940 ton per tahun dengan porsi terbesar dari jenis ikan pelagis kecil yaitu sebesar 3.235 .500 ton per tahun atau sebesar 52,54 persen, jenis ikan demersal 1.786 .350 ton per tahun atau 28,96 persen dan perikanan pelagis besar sebesar 975.050 ton atau sebesar 15,81 persen.

Potensi kelautan yang besar tersebut baru dimanfaatkan sebagian kecil saja. Potensi perikanan tangkap laut baru dimanfaatkan sekitar $62 \%$. Rendahnya pemanfaatan potensi sumber daya kelautan yang sedemikian besar, terutama disebabkan oleh : (1) pemerintah dan masyarakat masih mengutamakan eksploitasi daratan ; (2) teknologi eksplorasi dan eksploitasi lautan khususnya untuk penambangan minyak dan gas bumi serta mineral lainnya memerlukan teknologi tinggi; (3) kualitas sumber daya manusia yang terlibat dalam sektor kelautan masih rendah,khususnya perikanan tangkap; (4) introduksi teknologi baru dalam periknan tangkap tidak terjangkau oleh nelayan yang kondisi sosial ekonominya rendah; dan (5) sistem kelembagaan yang ada belum mendukung pengembangan sektor kelautan. Rendahnya pemanfaatan sektor kelautan tersebut tercermin dari rendahnya sumbangan sektor kelautan terhadap Produk Domestik Bruto (PDB) atas harga konstan 1993, yaitu pada tahun 1995 baru sebesar 12,83 persen (Budiharsono dan Kusumastanto, 1999).
Otonomi Daerah memberikan kewenangan lebih luas kepada daerah secara proporsional yang diwujudkan dalam pengaturan pembagian dan pemanfaatan sumberdaya serta kewenangan dalam mengurus kepentingan masyarakat setempat menurut prakarsa sendiri berdasarkan aspirasi masyarakat sesuai dengan peraturan perundang-undangan sehingga memberikan kesempatan bagi tiap daerah di dalam mengembangkan potensi sumber daya alamnya. Kabupaten Bone Bolango yang mempunyai garis pantai kurang lebih mencapai $75 \mathrm{Km}$ tentunya mempunyai potensi kelautan yang sangat besar, hal ini ditunjang oleh program unggulan Provinsi maupun Kabupaten. Posisi daerah selatan Kabupaten Bolango yang berbatasan langsung dengan Teluk Tomini, yang sudah terkenal mempunyai potensi yang belum dikelola secara optimal masih memerlukan perhatian pemerintah serta investor yang serius menanganinya. Selain itu juga ada pengembangan Diversifikasi Produk usaha Hasil Perikanan Tangkap yang dijalankan oleh ibu - ibu pesisir seperti otak - otak ikan, bakso ikan dan sosis ikan meskipun masih berskala kecil atau masih produksi Rumah Tangga.

\section{TINJAUAN PUSTAKA}

Setiap bangsa membutuhkan pembangunan. kemajuan di bidang ekonomi merupakan unsur penting dari setiap pembangunan. Tetapi unsur ini bukanlah satu-satunya, karena pembangunan tidak semata- 
mata fenomena ekonomi. Pada akhirnya pembangunan menuntut kita untuk memusatkan perhatian pada hal-hal yang lebih daripada sekedar sisi material dan financial dari kehidupan manusia. Pembangunan harus dimengerti sebagai suatu proses multidimensi yang melibatkan reorganisasi dari seluruh sistem sosial dan ekonomi yang ada.

Paling tidak terdapat tiga komponen dasar yang harus senantiasa muncul sebagai dasar pemikiran dan memandu secara praktis konsep-konsep yang diperlukan untuk memahami dengan lebih jelas kedalaman arti pembangunan yaitu : (1) Kebutuhan pangan yang berkelanjutan, (2) Harga Diri, dan (3) Kemerdekaan. Ketiga hal ini merupakan tujuan umum yang harus dicapai oleh setiap orang dan masyarakat ( Todaro,1995).

Menurut Arsyad (1999), Masalah pokok dalam pembangunan daerah adalah terletak pada penekanan terhadap kebijakan-kebijakan pembangunan yang didsarkan pada kekhasan daerah yang bersangkutan (endogenous development), dengan menggunakan potensi sumberdaya manusia, Kelembagaan dan sumberdaya fisik secara lokal. Orientasi mengarah kepada pengambilan inisiatif yang berasal dari daerah bersangkutan dalam proses pembangunan untuk menciptakan kesempatan kerja baru dan merangsang peningktan kegiatan ekonomi.
Mengenai corak pembangunan daerah, Arsyad (1999) mengemukakan bahwa perbedaan kondisi daerah membawa implikasi yang berbeda dalam corak pembangunan. Peniruan mentah- mentah pole kebijaksanaan yang pernah diterapkan pada suatu daerah belum tentu memberikan manfaat yang sama bagi daerah lainnya. Jika akan membangun suatu daerah, kebijakan yang diambil harus sesuai dengan kondisi (masalah, kebutuhan dan potensi) daerah yang bersangkutan.

\section{Konsep Manajemen Strategis}

Managemen strategis menurut Suwarsono (1994:6) dapat diartikan sebagai usaha manajerial menumbuhkembangkan kekuatan perusahaan untuk mengeksploitasi peluang bisnis yang muncul guna mencapai tujuan perusahaan yang telah ditetapkan sesuai dengan misi yang telah ditentukan. Komponen pokok dari manajemen strategis adalah:

a. Analisis lingkungan yang diperlukan untuk mendeteksi peluang dan ancaman.

b. Analisis profil perusahaan untuk mengidentifikasi kekuatan dan kelemahan.

c. Strategi yang diperlukan untuk mencapai tujuan dengan memperhatikan misi.

Menurut Salusu (1996:493), manajemen strategis adalah suatu cara untuk mengendalikan organisasi secara efektif dan efisien, sampai kepada implementasi garis terdepan, 
sedemikian rupa sehingga tujuan dan sasarannya tercapai.

Menurut Wahyudi manajemen strategis adalah suatu seni dan ilmu dari pembuatan (formulating), penerapan (implementing) dan evaluasi (evaluating) terhadap keputusan strategis antara fungsifungsi yang memungkinkan organisasi mencapai masa depan. Sedangkan Siagian (1995:15-42) mengatakan bahwa merumuskan manajemen strategis sebagai rangkaian keputusan dan tindakan mendasar yang dibuat oleh manajemen puncak dan di implementasikan oleh seluruh jajaran suatu organisasi dalam rangka pencapaian tujuan.

Tugas dari manajemen strategis adalah selalu mencari dan merumuskan isu-isu strategis. Isu-isu strategis ialah konflik di antara berbagai kekuatan atau konflik antara nilai-nilai yang dapat mempengaruhi kemampuan organisasi mencapai sasaran masa depan yang diinginkan. Dwiyanto (2001:1) menyatakan bahwa secara umum isu strategis diberikan batasan sebagai pertanyaan kebijakan mendasar atau tantangan kritis yang dapat mempengaruhi mandat, misi dan tata nilai organisasi atau manajemen, tingkat hasil dan pelayanan dan kombinasi keduanya, klien, pengguna atau anggaran pembiayaan, organisasi atau manajemen. Bagi organisasi publik identifikasi isu strategis seringkali memiliki peranan penting terutama dalam pengambilan keputusan. Pengambilan keputusan di organisasi publik pada umumnya bermula dari munculnya isu-isu tertentu yang perlu memperoleh respon dari organisasi itu.

\section{Pendapatan}

Pendapatan adalah Total Penerimaan (uang dan bukan uang) seseorang atau suatu rumah tangga selama periode tertentu. Pendapatan merupakan konsep aliran (flow concept). Ada bebarapa faktor yang mempengaruhi produktifitas, yaitu sebagai berikut :

a. Pendapatan dari Gaji dan Upah Gaji dan Upah adalah Balas jasa terhadap kesediaan menjadi tenaga kerja. Besar gaji/upah seseorang secara teoritis sangat tergantung dari produktifitasnya. Ada beberapa faktor yang memepengaruhi produktifitas, yaitu sebagai berikut :

b. Keahlian (Skill)

Keahlian adalah kemampuan teknis yang dimiliki seseorang untuk mampu menangani pekerjaan yang dipercayakan. Makin tinggi jabatan seseorang, keahlian yang dibutuhkan makin tinggi, karena itu gaji atau upahnnya makin tinggi.

c. Mutu Modal Manusia (Human Capital)

Mutu Modal Manusia adalah kapasitas pengetahuan, keahlian dana kemampuan yang dimiliki seseorang, baik karena bakat bawaan maupun hasil pendidikan dan latihan.

d. Kondisi Kerja (Working Condition) 
Yang dimaksud dengan kondisi kerja adalah lingkungan dimana seseoranag bekerja. Penuh resiko atau tidak. Kondisi kerja dianggap makin berat, bila resikso kegagalan atau kecelakaan kerja makin tinggi,untuk pekerjaan yang makin beresiko tinggi,upah atau gaji makin besar,walaupun tingkat keahlian yang dibutuhkan tidak jauh berbeda.

e. Pendapatan dari Aset Produktif Aset Produktif adalah aset yang memberikan pemasukan atas balas jasa penggunaannya. Ada dua kelompok aset produktif, pertama, Aset finansial seperti deposito yang menghasilkan pendapatan bunga, saham yang menghasilkan deviden, dan keuntungan atas modal bila diperjualbelikan. Kedua,aset bukan finansial seperti rumah yang memberikan penghasilan sewa.

f. Pendapatan dari Pemerintah (Transfer payment)

Pendapatan dari pemerintah atau penerimaan transfer adalah Pendapatan yang diterima bukan sebagai balas jasa atas input yang diberikan. Di negara-negara yang telah maju, penerimaan transfer diberikan, misalnya dalam bentuk tunjangan penghasilan bagi para penganggur (unemployment compensation) jaminan sosial bagi orang-orang miskin dan berpendapatan rendah.

g. Pendapatan uang dan Pendapatan Ekonomi
Pendapatan ekonomi adalah sejumlah uang yang dapat digunakan oleh keluarga dalam suatu periode tertentu untuk memebelanjakan diri tanpa mengurangi atau menambah aset neto. Sumber-sumber penghasilan ekonomi antara lain upah, gaji, pendapatan bunga dari deposito, pendapatan sewa, penghasilan trasnfer dari pemerintah dan lain lain.

\section{METODE PENELITIAN}

Untuk memperoleh pemahaman yang jelas tentang strategi pengembangan perikanan tangkap dan Olahannya dalam meningkatkan pendapatan asli daerah Kabupaten bone bolango.

1. Strategi Pengembangan Perikanan Tangkap dan Olahannya di daerah kabupaten Bone Bolango :

a. Memperbaiki sarana dan prasarana pembangunan kawasan pesisir dan laut sesuai dengan potensi pembangunan dan daya dukung lingkungan.

b. Menyebarluaskan informasi pasar tentang sumberdaya pesisir dan laut melalui media lokal/nasional secara kontinyu.

c. Mengembangkan model dan teknologi penangkapan atau pemanfaatan sumberdaya laut yang akrap lingkungan.

d. Mendukung lembaga/kelompok nelayan untuk mencari mitra secara langsung dengan investor. 
e. Memasyrakatkan dan menerapkan serta menegakan aturan - aturan yang berkaitan dengan wilayah pesisir dan laut.

f. Meningkatkan kemampuan teknik pemanfaatan dan pengelolaan komoditas pesisir dan laut dengan menggunakan model peralatan akrab lingkungan.

g. Membuka peluang kerja sama dengan lembaga keuangan/perbankan untuk mengatasi masalah modal.

h. Meningkatkan pendidikan dan keterampilan masyarakat/ nelayan pesisir dalam pemanfaatan pengelolaan sumber daya laut.

Luas Potensi Pengembangan Pembangunan Perikanan tangkap :

a) Luas wilayah pengelolaan \pm 500 $\mathrm{km}^{2}$

b) Potensi stok laut 1.226 .090 ton/tahun

c) Tingkat pemanfaatan $28,22 \%$ (434.769 ton) dari tahun $2004-$ 2008.

d) Armada dan Alat Tangkap Nelayan Bone Bolango

e) Mesin katintin 500 buah

f) Rumpon 200 unit

g) Keramba Jaring Apung 30 unit

h) Pukat 200 unit

i) Jumlah Tenaga Kerja ( Nelayan tangkap ), yaitu 2.076 atau 1.274 RTP

j) Pendapatan Asli daerah Kabupaten Bone Bolango pada tahun 2008 adalah 5.502.878.874 dimana jumlah tersebut adalah sangat rendah dibandingkan kabupaten pemekaran lainnya.

\section{Teknik Analisis Data}

Teknik analisis yang digunakan adalah teknik Analisis SWOT dengan pendekatan visi keberhasilan guna mengidentifikasi isu-isu strategisnya. Analisis SWOT didasarkan pada logika yang dapat memaksimalkan kekuatan (strength) dan peluang (opportunities), namun secara bersamaan dapat meminimalkan kelemahan (weakness) dan ancaman (threats) (Freddy Rangkuti 1999:18-19). Strength/kekuatan adalah suatu keunggulan sumber daya, keterampilan atau kemampuan lainnya yang relatif terhadap pesaing dan kebutuhan, dari pasar yang dilayani atau hendak dilayani oleh perusahaan. Weakness/kelemahan adalah keterbatasan atau kekurangan dalam sumber daya, keterampilan dan kemampuan yang dengan cara serius menghalangi kinerja efektif suatu perusahaan. Opportunities/peluang merupakan situasi utama yang menguntungkan dalam lingkungan perusahaan. Threats / ancaman merupakan situasi utama yang tidak menguntungkan dalam lingkungan perusahaan (wahyudi 1996:68-69).

Untuk mengetahui starategi pengembangan perikanan tangkap di wilayah bone pesisir menggunakan analisis SWOT. Analisis SWOT adalah singkatan dari Strenght atau kekuatan, Weakness atau kelemahan, Oportunity atau peluang, dan Treath atau ancaman. Analisis ini dapat 
didasarkan pada logika yang dapat memaksimalkan kekuatan dan peluang,namun secara bersamaan dapat meminimalkan kelemahan dan ancaman, (Rangkuti,2001). Menurut Salusu $\quad(1996,350)$ metode SWOT di gunakan untuk mencari alternatif strategi guna mendapatkan titik temu antara faktor-faktor strategi, baik dalam lingkungan internal maupun lingkungan eksternal.

Langkah - langkah menggunakan analisis SWOT adalah sebagai berikut :

1. Mengidentifikasi faktor Eksternal (FE) dan faktor Internal (FI) yang terdiri dari peluang dan ancaman (FE) serta kekuatan dan kelemahan (FI).

2. Merumuskan faktor-faktor eksternal dan internal guna mendapatkan alternatif strategi.

Tahapan-tahapan yang dilakukan untuk mengidentifikasi isu-isu strategis dengan pendekatan visi keberhasilan, strategi pengembangan Perikanan Tangkap Kabupaten Bone Bolango, berdasarkan pada panduan proses sebagai berikut (Bryson.1999:181) :

1. Meninjau kembali mandat, misi, kekuatan, kelemahan peluang dan ancaman organisasi.

2. Memilih pendekatan bagi identifikasi isu strategis, dalam hal ini pendekatan yang digunakan adalah pendekatan visi keberhasilan.

3. Bila isu strategis telah diidentifikasi, isu tersebut harus diurutkan berdasarkan prioritas, logis, atau urutan temporal sebagai pendahuluan bagi pengembangan strategi langkah berikutnya.

4. Menggunakan litmus test untuk mengembangkan beberapa ukuran tentang bagaimana strategisnya isu tersebut.

5. Diskusi yang sungguh-sungguh dan kesepakatan di antara pembuat keputusan untuk memecahkan isu-isu tersebut.

6. Pengembangan strategi

Adapun daftar pertanyaan pada Litmus Test terlihat pada tabel berikut: Tabel 2. Daftar Pertanyaan pada Litmus Tes.

\begin{tabular}{|c|c|c|c|c|}
\hline \multirow{2}{*}{$\begin{array}{l}\mathrm{N} \\
\mathrm{o}\end{array}$} & \multirow{2}{*}{ Uraian Pertanyaan } & Operasional & Nilai & Strategis \\
\hline & & 1 & 2 & 3 \\
\hline 1 & $\begin{array}{l}\text { Apakah isu tersebut merupakan agenda } \\
\text { strategis bagi pemerintah daerah? }\end{array}$ & Tidak & & Ya \\
\hline 2 & $\begin{array}{l}\text { Kapan isu strategis itu menjadi tantangan } \\
\text { atau peluang bagi daerah/ pemerintah } \\
\text { daerah }\end{array}$ & Jangka Pendek & $\begin{array}{l}\text { Jangka } \\
\text { Menengah }\end{array}$ & $\begin{array}{l}\text { Jangka } \\
\text { Panjang }\end{array}$ \\
\hline 3 & $\begin{array}{l}\text { Seberapa luas dampak isu tersebut bagi } \\
\text { organisasi/Pemda }\end{array}$ & 1 Sektor & $\begin{array}{l}\text { Beberapa } \\
\text { Sektor }\end{array}$ & Seluruh \\
\hline 4 & $\begin{array}{l}\text { Seberapa besar resiko/ peluang bagi } \\
\text { organisasi }\end{array}$ & $\begin{array}{l}10 \% \text { dari } \\
\text { anggaran }\end{array}$ & $10 \%-25 \%$ & $\begin{array}{l}\text { Lebih dari } \\
\quad \text { itu }\end{array}$ \\
\hline 5 & $\begin{array}{l}\text { Apakah strategi yang diperlukan } \\
\text { mensyaratkan: }\end{array}$ & Tidak & & Ya \\
\hline
\end{tabular}




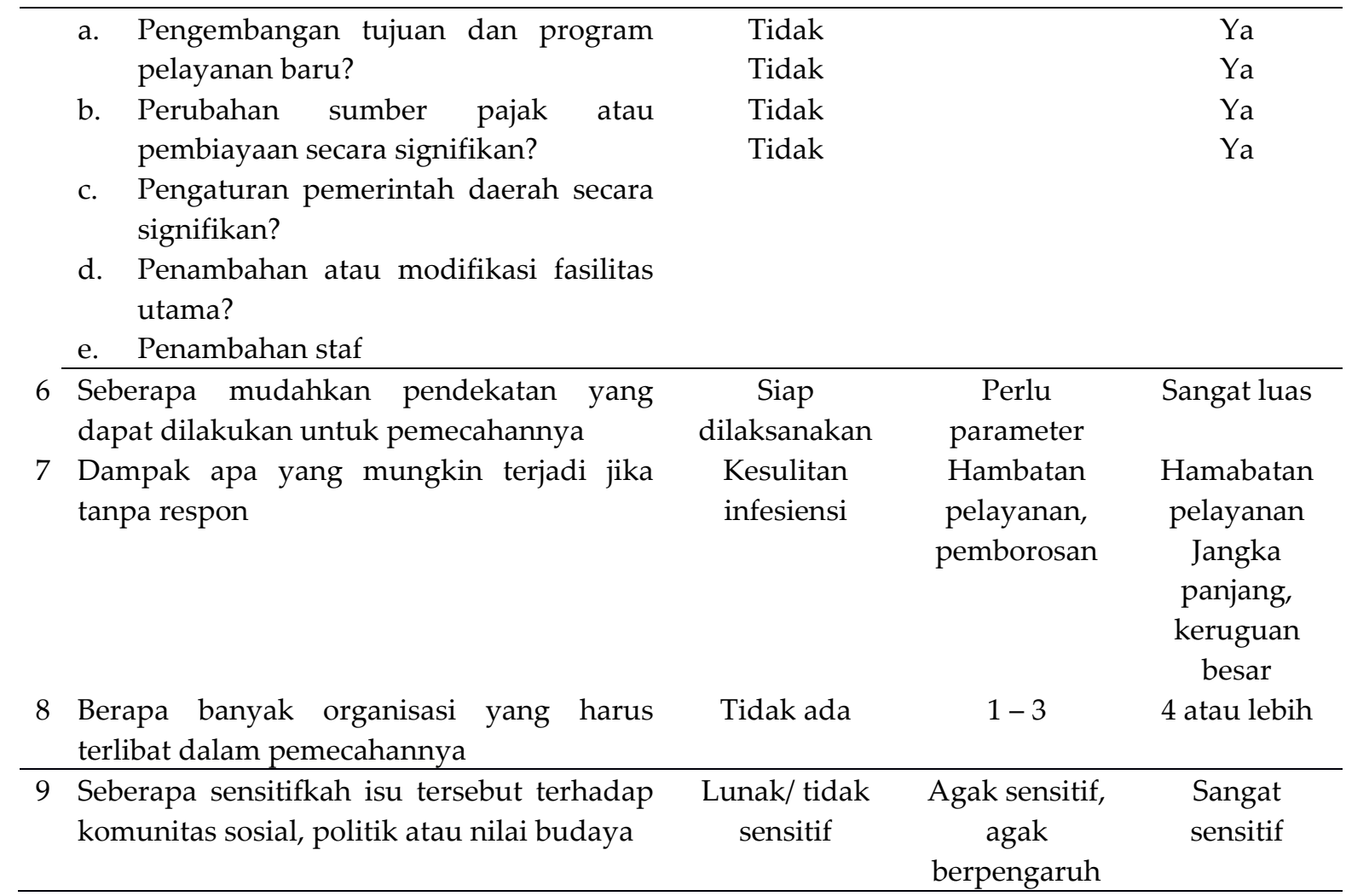

Sumber : ( Di Adaptasi dari Bryson, 2002)

Hasil jawaban instrumen Litmus Test, maka dapat diindikasikan bahwa untuk nilai 1 merupakan operasional sedangkan untuk hal yang bersifat strategis memiliki nilai 3, sehingga dapat dikategorikan sebagai berikut:

1. Kategori tidak strategis dengan jumlah nilai 13-21

2. Kategori cukup strategis dengan jumlah nilai 22-30

3. Kategori strategis dengan jumlah nilai 31-39

Di dalam memberikan rumusan strategi, ada empat strategi yang tampil dari hasil analisis SWOT (Salusu, 1996:364-366) :
Strategi SO, dipakai untuk menarik keuntungan dari peluang yang tersedia dalam lingkungan eksternal.

1. Strategi WO, bertujuan untuk memperbaiki kelemahan internal dengan memanfaatkan peluang dari lingkungan luar.

2. Strategi ST, akan digunakan organisasi untuk menghindari, paling tidak memperkecil dampak dari ancaman yang datang dari luar dengan memanfaatkan kekuatan yang ada.

3. Strategi WT, adalah taktik pertahanan yang diarahkan pada usaha memperkecil kelemahan internal dan menghindari ancaman eksternal. 


\section{PEMBAHASAN}

Lingkungan strategis, kendala dan peluang yang ada, pembangunan perikanan Kabupaten Bone Bolango diarahkan untuk mewujudkan visi pembangunan perikanan, yaitu "Mewujudkan Pengelolaan dan Pemanfaatan Sumberdaya Perikanan". Guna mencapai visi tersebut pihak Dinas Perikanan dan Kelautan Kabupaten Bone Bolango perlu memiliki misi yang jelas serta membuat strategi dalam menjalankan strategi tersebut.

Misi Pembangunan Perikanan Bone Bolango pada Lima tahun kedepan adalah :

1. Menata organisasi/ lembaga pelaku pembangunan perikanan dan kelautan serta penertiban pranata hukum dalam rangka memanfaatkan sumberdaya perikanan dan kelautan secara optimal dan bertanggung jawab.

2. Mengembangkan kegiatan ekonomi melalui pendekatan pengembangan sentra - sentra usaha serta pembangunan sarana dan prasarana sebagai pendorong kegiatan perekonomian.

3. Mengembangkan jiwa wirausaha dan memfasilitasi peran masyarakat petani ikan dan nelayan serta pelaku ekonomi dalam mengembangkan dunia perikanan dan meningkatkan pendapatan dan kesejahteraan masyarakat.
4. Menciptakan iklim berusaha yang kondusif bagi para pelaku ekonomi dalam mengembangkan dunia perikanan dan meningkatkan pendapatan daerah.

5. Memelihara dan mengatur daya dukung sumber daya kelautan perikanan serta jasa - jasa kelautan guna menjadi kesinambungan pembangunan

6. Menciptakan lapangan kerja dan kesempatan berusaha yang produktif serta peningkatan kualitas nelayan dan petani ikan

7. Menciptakan sumber daya manusia yang betul-betul memahami dan memiliki kemampuan dalam menghadapi semua permasalahan di bidang perikanan.

Dengan Visi dan Misi tersebut, maka pembangunan perikanan Kabupaten Bone Bolango ditujukan untuk : ( 1 ) meningkatkan taraf hidup masyarakat nelayan, ( 2 ) masyarakat nelayan dan petani ikan mampu menerima teknologi, ( 3 ) Peningkatan sarana dan prasarana guna menunjang peningkatan peningkatan produktifitas dan PAD, ( 4 ) Peningkatan peran serta masyarakat dan swasta dalam pengelolaan dan pemanfaatan sumberdaya perikanan dan ( 5 ) pengendalian pengelolaan dan pemanfaatan sumber daya perikanan dan kelautan. 


\section{PENUTUP}

\section{Kesimpulan}

1. Hasil Penelitian menunjukkan bahwa dari hasil analisis Swot diperoleh satu Strategi Pengembangan Perikanan Tangkap dan hasil Olahannya dalam meningkatkan Pendapatan Asli Daerah yang dijabarkan dalam beberapa aspek, yaitu :

a. Memperbaiki sarana dan prasarana pembangunan kawasan pesisir dan laut sesuai dengan pembangunan dan daya dukung lingkungan.

b. Menyebarluaskan informasi pasar tentang sumber daya pesisir dan laut melalui media local dan nasional secara terus menerus

c. Mengembangkan model dan teknologi tepat guna dan pemanfaatan sumber daya laut yang akrab lingkungan.

d. Mendukung kelompokkelompok nelayan untuk bermitra usaha mandiri

e. Memasyarakatkan dan menerapkan aturan-aturan yang berkaitan dengan pengelolaan perikanan tangkap.

f. Meningkatkan kemampuan masyarakat nelayan tentang pemanfaatan dan pengelolaan sumber daya perikanan tangkap

g. Meningkatkan produksi olahan hasil perikanan tangkap h. Berdasarkan hasil penelitian dapat disimpulkan dari beberapa isu strategis yang ada baik internal dan eksternal menunjukkan ada 8 isu strategis yang merupakan hal terpenting baik untuk pemerintah daerah dan masyarakat nelayan Bone Bolango.

2. Berdasarkan hasil penelitian dapat disimpulkan dari beberapa isu strategis yang ada baik internal dan eksternal menunjukkan ada 8 isu strategis yang merupakan hal terpenting baik untuk pemerintah daerah dan masyarakat nelayan Bone Bolango

\section{DAFTAR PUSTAKA}

Adisasmita H.R,1995 : Dasar - dasar Ekonomi wilayah. Graha Ilmu, Yogyakarta.

Arikunto, Suharsimi,2006 : Prosedur Penelitian,Suatu Pendekatan Praktik,penerbit Rineka Cipta,Jakarta.

Arsyad,L.1999 : : Pengantar Perencanaan dan Pengembangan ekonomi Daerah. BPFE.Yogyakarta

Budiharsono,S.2005: Pembangunan Wilayah Pesisir dan Lautan. PT Pradnya Paramita, Jakarta

Bumulo,Frahmawati 2011 Strategi Pengembangan Perikanan tangkap dalam Meningkatkan Pendapatan Asli Daerah di Kabupaten Bone Bolango 
Budiono,1999. Teori Pertumbuhan Ekonomi.BPFE,Yogyakarta

Djojohadikusumo.S,1992 : Dasar Teori Ekonomi Pertumbuhan dan Ekonomi Pembangunan,LP3ES,Jakarta

Rahardja,Pratama dan Manurung,Mandala,. 2010.
"Teori Ekonomi Mikro suatu pengantar". Edisi 4, LP,FEUI Jakarta.

Rahardja,Pratama dan Manurung,Mandala 2008. "Teori Ekonomi Makro suatu pengantar". Edisi keempat. LP,FEUI Jakarta. 